\title{
Depression and Hopelessness Levels of University Students According to Their Opinions on Finding Employment or Falling out of Labor Force in Turkey
}

\author{
Özlem Karakuş \\ Department of Social Services, Faculty of Health Sciences, Alaaddin Keykubat Campus, Selcuk University, Turkey
}

Copyright $\bigcirc 2018$ by authors, all rights reserved. Authors agree that this article remains permanently open access under the terms of the Creative Commons Attribution License 4.0 International License

\begin{abstract}
The aim of this study is to reveal the effects of the thoughts on university students' depression and hopelessness levels about whether to become employed or unemployed after graduation. The study sampling consists of 980 students from the departments of Selcuk University, such as the Faculties of Health Sciences, Law, Veterinary, Science, Communication, Economics and Administrative Sciences and Engineering. As study participants, 584 (59.6\%) men and 396 (40.4\%) women were defined using the random cluster sampling method. The data obtained from the survey were evaluated using the SPSS 20.0 software package program. Mean age rate of the students was 22 years ranging from 19 to 39 . The Beck Depression Inventory, the Beck Hopelessness Scale and the Demographic Information Form were used to collect data. In order to analyze the data, the logistic regression analysis was used. Our participants were classified into two as those feeling anxious due to difficulties in finding a job and those lacking of anxiety. In light of our study findings, 392 $(40.0 \%)$ students reported that they would be unemployed or experience difficulties in finding a job, whereas 588 $(60 \%)$ considered they would be employed easily after graduation. A statistically significant difference was observed in both groups as to the levels of depression and hopelessness $(\mathrm{p}<0.05)$. The fact that the students consider experiencing difficulties in finding jobs after graduating leads to a significant effect on their depression and hopelessness levels.
\end{abstract}

Keywords Depression, Hopelessness, Unemployed Anxiety, University Students

\section{Introduction}

Most high school students in Turkey make all their efforts to become a university student and are placed in different universities according to the scores of an undergraduate proficiency exam. Attending a university is perceived to start a profession and find a job by university students in Turkey [13]. Finding a job, especially in the public sector, after graduation is easier for the students in some departments, while more difficult for the students in other departments. Falling out of labor force or unemployment, however, can be assessed as an important problem for many undergraduate students $[5,11,4]$. According to Dokmen, while adaptation problems related to university and hostel life take precedence for the freshmen, anxiety felt for future life and concerns about finding a job become more significant for the third or fourth grade students [23].

Unemployment is a term, used to describe a part of skilled or unskilled individuals in a country wishing to work, but are deprived of a job, and those with these features are also called as the unemployed. The intriguing point with the definition is that unemployment is not a condition developing due to the fact that a part of skilled workers prefer not working and so their voluntary unemployment. On the contrary, unemployment arises from the fact that a part of skilled workforce fails to find an appropriate job and their involuntary unemployment although they wish to be a member of labor force [32]. In developing countries such as Turkey, unemployment still remains a challenge to be solved, and the statistics related to unemployment are quite higher, especially among post-graduate students. According to official statistics, monthly unemployment rate in Turkey was $10.6 \%$ in August, 2017 among general public and $20.7 \%$ as young unemployment rate as the highest of all segments [31].

Upon becoming unemployed, trained individuals feel that the investment and education process they have made for self-improvement are pointless, and as a result, they get into depression. Unemployment may make unemployed individuals feel themselves as worthless. Unemployment prevents educated individuals from fulfilling their 
expectations about life [20].

In today's world, employment is perceived as an individual's most fundamental right. Individuals' unable to find works cannot provide the basic necessities of life with themselves. As a result, such problems as anxiety, hopelessness and depression emerge. Furthermore, an individual will feel incapable of fulfilling his/her responsibilities, resulting in feelings of insignificance, unhappiness, loneliness and anger. These feelings lead to psychological collapse in the individual, and his/her self-respect will disappear. Also, with the effect of decreasing self-respect, individuals become self-hatred, and, depression develops or is witnessed in some individuals as a result of shutting themselves off, turning inwards and becoming isolated $[10,17]$.

Arising from deep sadness, pessimism, hopelessness and suffering, depression is a condition of apathy where an individual feels her/himself as insignificant, impotent and unmotivated. Certain disorders arise in depressed people's speech, movements and emotions. Depression is a common problem seen in daily life, but not always a pathological condition. Because of its frequent occurrence, depression is sometimes known as emotional flu [21].

For some individuals, emotional burnout may last for days, weeks and even months. Although maintaining routine daily activities, such individuals experience the symptoms of collapse. When the severity of emotional burning out increases and individuals cannot maintain their daily activities, this condition is categorized as psychotic depression [8].

Beck's [2] studies on depression and related factors suggest that the concept of hopelessness should always be taken into consideration in the evaluation of depression; namely, feelings led by hopelessness are closely related to depression [15].

Various studies report that most individuals with depression also feel deeply hopeless. Depressed individuals are scared that novel changes will take place in the life style they used to, and nothing will get better. A group of the depressed believes that nothing will be beneficial or helpful in solving their problems, and so may even wish to die. They may start considering that death is a better option [24]. Hopelessness, loss of interest and lack of energy are the major symptoms of depression. Briefly, hopelessness means that an individual feels pessimistic about the future, resulting in depression which may lead to suicide $[25,26]$. In literature, seen as one of the reasons of depression, hopelessness is accompanied by and studied in general by learned helplessness. This term expresses depressed individuals' motivational, cognitive and emotional status that no change will occur in their behaviors due to the results of events. In other words, the events will develop independently of the individual. Feeling uncontrolled on events prevents an individual from feeling motivated to develop new behaviors, and failed to form a connection between new behaviors. The previous also prevents new learning processes, and repeated experiences create depression-like mood disorders [27].

Both hopefulness and hopelessness are the probable reflections of an individual's opportunities to achieve his/her real goals in the future. Hopefulness and hopelessness represent opposite expectations. Whereas there is a foresight in hopefulness where the plans to reach the goal will be achieved, a presupposition of failure is present in hopelessness. These two extreme expectations vary from person to person or situation to situation according to when and how the anticipated situation will come about [12]. Signs accompanied by hopelessness are the feelings of worthlessness, desperation, unhappiness, indecisiveness, guilt and inability to maintain his/her business. Unemployment and poverty lead to physical disorders, somatic complaints, stress disorders and mental health disorders, such as depression, hopelessness, loss of self-esteem, anxiety and behavioral disorders [18].

In the light of the abovementioned data, the aim of the present study is to reveal the effects of university students' thoughts about whether to find a job or to fall out of labor force after graduation on the levels of depression and hopelessness.

\section{Materials and Methods}

\subsection{Research Model}

This is a descriptive study designed to determine the effects of university students' thoughts about whether to find a job or fall out of labor force after graduation on their depression and hopelessness levels.

\subsection{Study Group}

The sample of the study consists of 980 students from the departments of Health Sciences, Law, Veterinary, Science, Communication, Economics and Administrative Sciences, and Engineering in Selcuk University. Of all participants, $584(59.6 \%)$ boy and 396 (40.4\%) girl students were selected using the random cluster sampling method. The data entry and statistical analyses were performed with SPSS software (Statistical Package for the Social Sciences) program for Windows version 20.0 (SPSS, Chicago, IL, USA). Students'ages level ranged from 19 to 39 , and the average age was 22 (SD 1.75). Among our study participants, $591(60.0 \%)$ were composed of the third grade students, while $388(40.0 \%)$ were from the fourth grade.

\subsection{Data Collection Tools}

A demographic information form, the Beck Depression Inventory (BDI) and the Beck Hopelessness Scale (BHS) were used as data collection tools. The question asked to 
find out students' opinions about future employment status were sought in the form of a yes-no question, and was placed just the bottom of the demographic information form.

\subsection{The Beck Depression Inventory}

To measure physical, emotional, cognitive and motivational symptoms seen in depression, BDI was developed by Beck [1]. The aim of this scale is to determine the level of depression symptoms and the degree of intensity without diagnosing depression. BDI includes 21 self-assessment items with four options in each category. Each item is scored between 0 and 3 , and the total score ranges from 0 to 63 . The validity and reliability study in our country was made by Hisli, and the Cronbach alpha was found to be .80 . [16]. However, the Cronbach alpha was found to be 78.1 in our study.

\subsection{The Beck Hopelessness Scale}

BHS was developed by Beck [2] to measure individuals' negative expectations toward the future. BHS is a type of self-assessment consisting of 20 items. The range of scores on the scale is between 0 and 20. Any response matching the response key gets 1 point; any response not matching the response key gets 0 point. The scale evaluates 3 factors: feelings about the future, loss of motivation and expectations about the future. The validity and reliability study of BHS in our country was made by Durak, and the Cronbach alpha was found to be .86 [3]. It has been shown to be a valid and reliable scale to measure hopelessness both for individuals within normal limits and those with psychiatric and chronic-physical illnesses. In our study, the Cronbach alpha was found to be 78.1 .

\subsection{Data Analysis}

A total of 980 students were included into the research data. The data and analyses were performed with SPSS software program for Windows version 20.0 (Chicago, IL, USA). In the analysis of the data, descriptive (frequency, descriptive), statistical and logistic regression were used.

\section{Findings}

Because our reference value was detected as "Yes" in the abovementioned section, we postulated our results based on this condition. That is, university students' negative thoughts about falling out of workforce and not finding a job after graduation bring about a significant effect on the levels of depression and hopelessness. This effect has a negative side. In other words, when a university student considers falling out of labor market, he or she gets into depression and experiences hopelessness. Exp (B) column in Table 1 accounts for probability, however. A one-unit change in depression level leads to a 0.971-fold increase from "yes" to "no" in the thought about becoming unemployed after graduation. In the analysis performed, because reference category was accepted as "yes" $(0=$ yes $)$, there was no significant difference between the thought of becoming unemployed after graduation and the levels of depression and hopelessness $(\mathrm{p}<.05)$.

\section{Discussion}

The fact that university students consider falling out of workforce and not finding a job during post-graduation period leads to a significant effect on students' depression and hopelessness levels. Young individuals without economic independence have to live with their families, cannot set up an economically independent life, and descend into a mood of pessimism about their future [11, 14]. In this regard, unemployment has not only negative impacts on quality of life and relations among individuals, but causes some negative emotions such as depression, anxiety, anger and hopelessness, as well. Additionally, it may increase the risk of suicide, as well as alcohol and substance abuse [20].

In a study performed by Ustun et al [33], it was reported that the average hopelessness score of students in the departments where it is difficult to find a job in state institutions is higher than those studying in the departments where such opportunities are more readily available. According to Dereli and Kabatas [11], students considering that they will be employed within 6 months after graduation are more hopeful than other groups. In the study by Kırımoglu [22], the level of hopelessness among those with concerns about finding a job was found to be lower. In another study, Ceyhan [6] reported that candidate teachers considering that they would not find a job related to teaching after graduation experienced higher level of hopelessness than those thinking that they would find. 
Table 1. Results of the logistic regression analysis for depression and hopelessness levels felt by the students considering unemployment and employment after graduation

\begin{tabular}{|l|c|c|c|c|c|c|c|c|}
\hline & B & Standard Error & Wald & SD & p & \multirow{2}{*}{ Exp (B) } & \multicolumn{2}{|c|}{$95 \%$ CI for Exp (B) } \\
\cline { 4 - 10 } & & & & & & & Lower & Upper \\
\hline Depression Inventory & -.029 & .009 & 10.538 & 1 & .001 & .971 & .954 & .989 \\
\hline Hopelessness Scale & -.084 & .020 & 17.649 & 1 & .000 & .920 & .885 & .956 \\
\hline Constant & 1.221 & .646 & 3.578 & 1 & .059 & 3.392 & & \\
\hline $\begin{array}{l}\text { Cox \& Snell } R \text { Square }=.070 \\
\text { Nagelkerke } R \text { Square }=.094 \\
\text { Prediction rate }=60.2 \%\end{array}$
\end{tabular}

Hopelessness results from the absence of hope. So, in order to refer to and understand hopelessness, the term of hope should be defined as "a quality giving the feeling of being worthy and motivating an individual to take positive action" [19]. The most important feature of hope is the anticipation and belief that there will be a solution with positive developments, and plans will be achieved [7].

In the case of losing a job or long-term unemployment, individuals experience some problems such as tension, depression, feelings of incompetence, sleeplessness, fear and anxiety. Moreover, with uncertainties about the future and feelings of incompetence, people encounter problematic and difficult situations to be overcome [34]. In addition to the feelings of hopelessness and anxiety, unemployed young people may experience depressive and psychosomatic symptoms. Similarly, their self-respect might be damaged [20]. It was found that unemployed individuals were more depressed than those employed, and their level of depression decreased when they were re-employed [30]. Furthermore, people unemployed for more than 60 days were reported to have very high levels of anxiety and depression, somatic problems, emotions of resentment and paranoia, compared to the employed ones [9].

\section{REFERENCES}

[1] Beck, A. T. (1961). An inventory for measuring depression. Arch Gen Psychiatry 4: 561-571.

[2] Beck A.T, A Weissman, D. Lester, L. Trexler (1974). Theassessment of pessimism. The Hopelessness Scale. J Consult Clin Psychol 42(2):861-5.

[3] Durak, A. (1994). Beck Umutsuzluk Ölçeği (BUÖ) geçerlik ve güvenirlik çalışması. Türk Psikoloji Dergisi 9(31):1-11.

[4] Büyükşahin-Çevik, G., and M. S. Yıldız. (2016). Pedagojik Formasyon Ögrencilerinde Umutsuzluk ile Mutluluk Arasındaki İlişkide Benlik Saygısının Aracılık Rolü.” Dicle Üniversitesi Ziya Gökalp Ĕgitim Fakültesi Dergisi 27: 96-107.

[5] Çelikel, F. Ç., and Ü. Erkorkmaz. (2008). "Üniversite ögrencilerinde depresif belirtiler ve umutsuzluk düzeyleri ile ilişkili etmenler.” Nöropsikiyatri Arşivi, 45: 122-129.
[6] Ceylan, R. (2004). Entegre Eğitime Katılan ve Katılmayan Engelli Çocukların Annelerinin Depresyon ve Umutsuzluk Düzeylerinin İncelenmesi. Ankara: Ankara Üniversitesi Fen Bilimleri Enstitüsü Yayımlanmamış Doktora Tezi.

[7] Cheavens J. S., D. B. Feldman, J. T. Woodward, and C. R. Snyder. 2006. "Hope in Cognitive Psychotherapies: On Working with Client Strengths." Journal of Cognitive Psychotherapy: An International Quarterly 20 (2): 135-145.

[8] Cüceloğlu, D. (2005). İnsan ve Davranış. İstanbul: Remzi Kitabevi

[9] Darity, W. J. and Goldsmith, A. H. 1993. "Unemployment, Social Psychology and Unemployment Hysteresis."Journal of Post Keynesian Economics 16 (1): 55-75.

[10] Demirkan, B. (2014). Türkiye'deI şsizliğin Sosyolojik ve Psikolojik Etkileri. Ankara:

[11] Dereli, F., and S. Kabatas. 2009. "Sağlik Yüksekokulu Son Sınıf Öğrencilerinin İş Bulma Endişeleri ve Umutsuzluk Düzeylerinin Belirlenmesi.” Yeni Tip Dergisi 26: 31-36.

[12] Dilbaz, N., and G. Seber. (1993). "Umutsuzluk Kavram1: Depresyon ve İntiharda Önemi.” Kriz Dergisi 1: 134-138.

[13] Dursun, S. and S. Aytaç. (2009). "Üniversite Öğrencileri Arasinda İşsizlik Kaygisi." Uludağ Üniversitesi İktisadi ve Ídari Bilimler Fakültesi Dergisi 1:71-84.

[14] Ersoy-Kart, M. and H. E. Erdost. (2008). "Unemployment Worries Among Turkish University Students." Social Behavior and Personality 36 (2): 275-288.

[15] Göller, L. (2010). Ergenlerin Akılcı Olmayan İnançları ile Depresyon-Umutsuzluk Düzeyleri ve Algıladıkları Akademik Başarıları Arasındaki Ilişkiler. Erzurum: Atatürk Üniversitesi Sosyal Bilimler Enstitüsü Yayımlanmamıș Yüksek Lisans Tezi.

[16] Hisli N. (1989). Beck Depresyon Envanterinin Üniversite Öğrencileri İçin Geçerliği ve Güvenirliği. Psikoloji Dergisi 7:3-13.

[17] Karataş, K. (1996). Gençİşsizliği: Ekonomik, Toplumsal ve Ruhsal Sonuçları. Ankara: Sosyal Hizmetler Uzmanları Derneği Genel Merkezi Yayınları.

[18] Kaya, B. (2007). Depresyon: Sosyo-Ekonomik ve Kültürel Pencereden Bakış, KlinikPsikiyatri 10(6): 11-20.

[19] Kemer, G. and K. Atik. (2005). "Kursalve İl Merkezinde Yaşayan Lise Öğrencilerinin Umut Düzeylerinin Aileden Algılanan Sosyal Destek Düzeyine Göre Karşılaştırılması." M.Ü. Atatürk Eğitim Fakültesi Eğitim Bilimleri Dergisi 21: 161-168 
[20] Kıcır, B. (2010). Üniversite Son Sinıf Öğrencilerinde İssizlik Kaygısı: Psikolojik Etmenler Açısından Bir Inceleme. Ankara: Ankara Üniversitesi, Sosyal Bilimler Enstitüsü, Çalısma Ekonomisi ve Endüstri İlişkileri Anabilim Dalı, Yüksek Lisans Tezi.

[21] Kıratl1, D. (2001). Depremzede Olan ve Olmayan Gençlerin Kaygl ve Depresyon Düzeylerinin Incelenmesi. Ankara: Ankara Üniversitesi Fen Bilimleri Enstitüsü Yüksek Lisans Tezi.

[22] Kırımoğlu, H. (2010). “Türkiye'deki Beden Eğitimi ve Spor Yüksek Okulu Son Sınıf Öğrencilerinin İstihdam Sorunu Açısından Umutsuzluk Düzeylerinin İncelenmesi." Kastamonu Eğitim Dergisi 18 (1): 37-46.

[23] Koç, M., and Ü. Polat. (2006). "Üniversite Öğrencilerinin Ruh Sağlığı.” Uluslararası İnsan Bilimleri Dergisi3 (2): $1-22$.

[24] Köroğlu, E. (2006). Depresyon Nedir? Nasıl Baş Edilir? Ankara: HYB Yayınları.

[25] O'connor, R. C., H. Connery, and W. M. Cheyne. 2000. Hopelessness: The Role of Depression, Future Directed Thinking and Cognitive Vulnerability. Psychology, Health and Medicine, 5 (2):155-16.

[26] Ottekin, N. (2009). Ailelerinden Ayr Olarak Öğrenim Görmekte Olan Üniversite Öğrencilerinin Benlik Saygısı ve Umutsuzluk Düzeylerinin Incelenmesi. Konya: Selçuk Üniversitesi Sosyal Bilimler Enstitüsü Eğitim Bilimleri Anabilim Dalı Yayınlanmamış Yüksek Lisans Tezi.

[27] Pervin, L. A. (1993). Personality: Theory and Research.
New York: John Wiley and Sons, Inc.

[28] Seber, G. (1991). Beck Umutsuzluk Ölçeğinin Geçerliliğive Güvenirliği Üzerine Bir Çalı̧̧ma. Eskişehir: Anadolu Üniversitesi Tıp Fakültesi, Psikiyatri Anabilim Dalı Doçentlik Tezi.

[29] Seber, G., N. Dilbaz, C. Kaptanoğlu, and D. Tekin. (1993). "Umutsuzluk Ölçeği: Geçerlilik ve Güvenirliği."Kriz Dergisi 1 (3): 139-142.

[30] Tiggemann, M. and H. A. Winefield. (1984). "The Effect of Unemployment on the Mood, Self Esteem, Locus of Control and Depressive Effect of School-Leavers." Journal of Occupational Psychology 57 (1): 33-42.

[31] Turkish Statistical Institute. (2017). Retrieved November 28, 2017, from http://www.tuik.gov.tr/Start.do;jsessionid=HyKchhJPRBPf QngGKbh41Q22h190yLykgsb3pwyhRx2NdhRX641b!-162 0584608

[32] Ünsal, E. M. (2003). MakroIktisat (5.Bask1), Ankara: Turhan Kitapevi.

[33] Üstün, G., Ș. Dedekoç, T. Kavalalı, F. Öztürk, Y. Sapcı, and S. Can. (2014). "Üniversite Son Sınıf Öğrencilerinin İş Bulmaya İliskin Umutsuzluk Düzeylerinin İncelenmesi." Amasya Üniversitesi Eğitim Fakültesi Dergisi(2): 200-221

[34] [34] Yılmaz, T., F. Fidan, and V. Karataş. (2004). "İşsizliğin Sosyo-Psikolojik Sonuçları: Sosyo-Demografik Özelliklere Göre Bireyin Tutumları Bir Alan Araştırması."Sosyal Siyaset Konferanslarl 48: 1 